\title{
The effect of political trust and trust in European citizens on European identityf
}

\author{
SOETKIN VERHAEGEN, MARC HOOGHE* AND ELLEN QUINTELIER \\ Centre for Citizenship and Democracy, University of Leuven, Leuven, Belgium
}

\begin{abstract}
In the literature, two approaches toward the development of a European identity can be distinguished. Society-based approaches assume that the most important foundation for the development of a European identity is trust toward other European citizens as this allows Europeans to identify with the European Union as a community of citizens and values. The institutional approach, on the other hand, assumes that a shared European identity is predominantly based on trust in political institutions. In this paper, we use the results of the IntUne Mass Survey 2009 ( $n=16,613$ in $16 \mathrm{EU}$ member states) to test the relationship between social and political trust on the one hand, and European identity on the other. The results suggest that trust in other European citizens is positively associated with European identity, but trust in the European political institutions has a stronger relation with European identity. This could imply that efforts to strengthen European identity cannot just rely on a bottom-up approach, but should also pay attention to the effectiveness and the visibility of the EU institutions and the way they are being perceived by European citizens.
\end{abstract}

Keywords: European identity; social trust; political trust; European Union

\section{Introduction}

The perceived lack of legitimacy of the European Union has reinvigorated the academic debate about the determinants of support for the EU political system (Moravcsik, 2002). Ultimately, this form of diffuse support among the population is dependent on the question whether citizens identify with the political system, with the community it represents and the norms according to which the system functions (Easton, 1965; Beetham and Lord, 1998). Historically, processes of nation-building have tried to promote not only collective identities, but also a sense of loyalty toward the political system itself. It is assumed that this effort to establish legitimacy is most successful if citizens perceive the political system as not only reflecting the preferences of the citizenry, but also as serving the community they belong to in an effective manner (Harteveld et al., 2013; Braun and Tausendpfund, 2014). The evidence assembled thus far, however, suggests that a feeling of belonging to the European Union is but weakly developed. Our main research question is to determine whether this European identity is most strongly associated with trust in other Europeans

* E-mail: Marc.Hooghe@soc.kuleuven.be

$\ddagger$ The original version of this article was submitted without one of the authors credited. A notice detailing this has been published and the error rectified in the online PDF and HTML copies. 
(society-based approach), or with trust in the political institutions of the EU (institutional approach). The European Union can be conceptualized as a still emerging political system, that has not (yet) achieved full democratic legitimacy, and apparently the current economic crisis has done little to strengthen the popular appeal of the EU (Haller, 2008; Boomgaarden et al., 2011; Hobolt, 2012; Risse, 2014). The success of Eurosceptic political parties makes clear that the development of support for European integration should not be considered as a straightforward process (Checkel and Katzenstein, 2009). Despite the fact that the European Union has consolidated its position as a major political entity, it seems clear that a common European identity is not yet widespread (Habermas, 2011).

In the literature, we can distinguish two different approaches for investigating the development of a European identity (Risse, 2010). On the one hand, various authors have argued in favor of a society-based approach, as they assume that this development requires that European citizens identify with other Europeans in order to establish an authentic European community of citizens. Habermas (2011), most notably, has argued that a democratic community of citizens needs to be established before public opinion in Europe will accept the EU as a legitimate form and level of governance. This line of reasoning leads to the expectation that trust in other European citizens will play an important role in the establishment of a European sense of identity. This feeling of a shared identity can ultimately determine the legitimacy of the process of European integration (Risse, 2014). On the other hand, proponents of a neo-functionalist institutional perspective have argued that the European institutions mostly will be judged on a perception of their performance level (Pierson, 1996). If the EU institutions succeed in delivering on their promises, in terms of economic growth, co-operation, and prosperity, this will lead to a more positive assessment of the comprehensive project of European integration by the citizenry (Verhaegen et al., 2014). Within this perspective, the process of constructing a European identity is mostly elite-initiated: if the European political elites manage to function in an effective manner and to convey that message to public opinion, it is assumed that citizens will subsequently develop an attachment to this policy level (Haller, 2008). This would imply that trust in political institutions serves as a main building block for the development of a European identity because of the fact that citizens trust the political system, they develop a sense of identity that incorporates the EU perspective.

In this article, our goal is to compare the empirical validity of both approaches. We want to ascertain whether identification with the European Union is related to trust in other European citizens, or with trust in the political institutions that have shaped the EU. In order to ascertain the empirical validity of both claims, we rely on the notion of trust as this concept captures most closely the kind of affective linkage that is crucial to assess the legitimacy of a political system (Newton, 1999; De Vroome et al., 2013). Although in the literature numerous definitions of the concept of trust can be found, for the purpose of the current article, it suffices to mention the more general definition, stating that actors express trust if they expect their interaction partner to behave in a 
trustworthy manner, that is, in a manner that is benign or positive toward one's own interests (Cook, 2001). Trust toward political institutions implies a form of diffuse support and acceptance of the legitimacy of these institutions (Easton, 1975). If the process of European integration is based on a shared feeling of community among European citizens, this would imply that Europeans trust other European citizens and that this feeling of trust allows them to develop a European identity. The institutionalist approach, on the other hand, would predict that trust in political institutions is crucial for developing a European identity. If citizens have the feeling that political institutions deliver on their promise, this will be associated with a stronger identification with the EU policy level. The question we want to investigate, therefore, is whether trust in other Europeans, or trust in the political institutions of the EU, should be considered as the strongest correlate of identification with the European Union.

In the following sections, we will first present the current state of the art in studies about social and political trust in the EU context, and define our key concepts of European identity, social, and political trust. Second, we describe the data used to test the relationship between both types of trust and European identity. Third, multilevel regression analyses are carried out to test this relationship and fourth, the implications or our results for the broader debate on European legitimacy are discussed while we also consider the limitations of the current study.

\section{Literature}

\section{European identity}

In the debate about the political legitimacy of the European Union, it has been stressed repeatedly that the development of a European identity will determine the long-term stability and success of the process of European integration (Risse, 2010; Habermas, 2011). This approach assumes the emergence of a direct and positive relation between the citizens of Europe and the EU level of political decision making. Since the 1992 Maastricht Treaty, European citizenship has been established as a formal construct by granting citizens direct rights and guaranteeing these rights by European law. One of the explicit goals of introducing this legal category of citizenship was to promote a shared feeling of community among European citizens. This feeling of belonging is referred to as 'European identity,' which has become a booming field of research within European studies (Jentges et al., 2007). European identity has been defined as the feeling of belonging to the European Union, and to conceive this level as an integral part of one's own social identity (Kaina, 2009; Risse, 2010). ${ }^{1}$ Bruter (2008) has made the claim that European identity entails a number of distinct components, and he proposes to make a distinction between cultural and civic dimensions. The cultural dimension is based on the expectation that Europeans share a

\footnotetext{
${ }^{1}$ In line with the literature, and for the sake of clarity, we will use the terminology of 'European identity'. It has to be clear, however, that this explicitly refers to identifiying with the European Union, and not with Europe as a continent, or a historical or cultural entity.
} 
common culture, while the civic dimension is constructed mostly on the framework of rights and duties as defined by the European treaties and subsequent legislation. Adhering to a European identity means that citizens consider the European level as a salient level to define their self-identity and to consider themselves as belonging to a distinct social group. Previous studies have shown that the occurrence of a European identity can partly be explained by the effect of cognitive skills, transnational mobility, media, personal characteristics and even attitudes toward the member state one belongs to (Faas, 2007; Duchesne and Frognier, 2008; Fligstein, 2008; Sigalas, 2010). While these studies have shown that European identity can indeed be operationalized and measured in a valid manner, simultaneously these studies have shown that, for most Europeans, this European identity is not that salient or strong at all. The question therefore remains whether European identity indeed can be considered as a strong building block to ensure the future process of further European integration (Fligstein et al., 2012). In this study, we follow a standard measurement of European identity, as it has been used in a number of previous studies, conceptualizing European identity as a feeling of belonging to the EU-based community (Bruter, 2003; Citrin and Sides, 2004; Herrmann and Brewer, 2004; Fligstein, 2008; Risse, 2010). European identity is seen as an aspect of one's social identity, which provides a stable linkage mechanism between the individual perception of the self and the social group to which a person belongs (Brewer, 2001). It places the individual within the structure of a social group and attaches a positive meaning to this group membership. European identity will serve as the main dependent variable in our analysis.

\section{Social trust}

While there is a consensus on the importance of a European identity, there is much more disagreement about the question of how this European identity can be developed. Proponents of the society-based approach to the development of European identity have argued that building affective bonds with other European citizens can be considered as a first condition for identification with the European Union as a political community (Delhey, 2007; Klingemann and Weldon, 2013). Developing this sense of community implies that there is at least a rudimentary form of a trusting relationship with the other members of the community. Scheuer and Schmitt (2009: 559) summarize this assumption in their statement 'Trust is a fundamental condition for the development of a sense of community.' Trust indeed facilitates forms of co-operation and pursuing collective action. The absence of trust renders it less likely that actors will interact with others in order to reach common goals (Putnam, 1993). Kaina (2006: 199) therefore argues that trust in other citizens is the starting point for the development of a functional and cohesive community. 'Since the growth of a shared sense of community requires a space of common experiences, interpersonal relations based on trust create the opportunity structures of such experiences.' A similar claim has been made by Uslaner (2002), who argued that trust in others is a prerequisite for collective action within a community. 
Trusters believe in a common culture, underlying shared values, value diversity, and common understanding. The expectation is that other community members will behave in a manner that is in accordance with the basic norms and values that are prevalent within society. Klingemann and Weldon (2013) have demonstrated that there are substantial differences in the level of trust attributed to European citizens depending on the member state they originate from. While trust levels are high for citizens in the stable member states with high levels of economic development, they tend to be much lower for citizens in the Southern and more recently accessed member states. They argue, however, that these different levels of trust stem from cultural and economic differences between these groups of member states. Klingemann and Weldon expect that while these differences might be an obstacle to the development of mutual trust in the short-run, citizens from different member states 'can learn to trust one another and build a sense of community over time' (Klingemann and Weldon, 2013: 457). Typically, it is expected that exchange and interaction like in, for example, the Erasmus student mobility program, will lead to a more trusting relation between European citizens originating from different member states and thus stimulates the European identity of the participants (Mitchell, 2015). In this view, too, identity is seen as a dependent variable that is developed as a result of various experiences and attitudes. Previous research also shows that respondents do make meaningful distinctions with regard to the level of trust they express toward specific outgroups (Gerritsen and Lubbers, 2010). This line of reasoning, therefore, leads to the hypothesis that if citizens develop trust in their fellow-Europeans, they will identify more strongly with the European Union as a political project.

\section{Trust in political institutions}

Other authors, however, have argued that the development of a European identity depends on the way political institutions are being evaluated by the population (Føllesdal, 2006). This evaluation can be summarized in the notion of political trust. Political trust is trust in 'the core institutions of the state, including the legislature, executive, and judicial branches of government' (Norris, 2011: 29). This definition does not reflect or include trust in specific office holders or politicians, but it refers to a very generalized form of trust in the institutions governing a political system. As such, it can be considered as a form of diffuse support toward the political system and its core values as a whole, and it does not reflect agreement with specific policy decisions (Easton, 1965; Marien, 2011). Political trust can be considered as the strongest expression of diffuse support among the population (Zmerli and Hooghe, 2011). On the one hand, political trust is based on an evaluation of the functioning and the performance of the political system, but it also determines the willingness of citizens to comply with decisions that have been taken by the political system, as these are considered to be legitimate (Easton, 1975). Previous studies have shown that there is a positive correlation between trust in the national political institutions and trust in the European Union (Muñoz et al., 2011; Arnold et al., 2012). 
This means that there is no zero-sum relation between the national and the European level as is often assumed. National governments decide on the process of European integration, and if citizens have a trusting attitude toward their own national institutions, apparently this is also extended toward the European Union. A negative interpretation of this relation might be that European integration is seen as an elite-initiated process: apparently citizens hold their own national elites responsible for the results of the process of European integration (Loveless and Rohrschneider, 2011). A more positive interpretation is based on the assumption that loyalties are not just based on identification with community members, but also more directly on identification with the political institutions that govern the community (Easton, 1965). In the past too, the development of national identities was not just founded on a shared bond among citizens, but also on a direct affective bond between the citizen and the state institutions (Tilly, 1975). Newly emerging nation states and other political systems actively tried to develop a bond of loyalty between the citizens and the political institutions. The way in which the state system operates and is successful therefore, also determines the emergence of specific political identities (Tilly, 1992). This historical process is well documented, and there is no apparent reason why a similar process would not occur for the European Union as well. This would imply that when citizens identify as EU citizens, they relate these feelings first to the political institutions, as would be shown by a significant relationship between levels of political trust and European identity. This is what we call the top-down construction of European identity: the role of institutions is considered to be more important in this perspective than the role of societal determinants. This neo-functionalist line of reasoning would mean that the political elite first created EU institutions, which were in turn instrumental in shaping the feeling of citizenship (Shore, 2000; Klingemann and Weldon, 2013).

The basic question in this article is to determine how both forms of trust relate to European identity. Following the literature on identity formation, our assumption is that trust has an effect on the development of identity. In the concluding section, however, we further discuss this problem of causality assumptions.

\section{Data and methods}

In order to establish whether European identity is associated with a positive evaluation of European society, or rather of political institutions, we need to rely on a data set in which both concepts are included. The data of the IntUne Mass Survey Wave 2 were collected in 2009 in 16 EU member states (Cotta et al., 2009). ${ }^{2}$ It is considered as a high quality and representative data gathering effort for these member states (Sanders et al., 2012). About 1000 respondents were interviewed in every participating country, except for Austria where only 503 completed

\footnotetext{
${ }^{2}$ Countries included in the study are Austria, Belgium, Bulgaria, Denmark, Estonia, France, Germany, Greece, Hungary, Italy, Poland, Portugal, Slovakia, Slovenia, Spain, and the United Kingdom.
} 
interviews were included. The average response rate for the data collection is 32.1 percent, but nevertheless the data set still can be considered as representative for the adult population of those 16 member states.

We use multilevel regression analysis as this method takes into account the clustered structure of the data (individuals are clustered in member states; Hox, 2010). Moreover, this type of analysis is especially well suited for clustered data with unequal cluster sizes, which is the case in the Intune Mass Survey, and it allows for adding explanatory and control variables on the country level. Finally, a first analysis suggests that a substantial part of the variance in European identity is situated at the country level as we observe an intraclass correlation of $4.1 \%$ on the country level. Using multilevel regression analysis takes this into account. While it has to be acknowledged that the number of countries included in this survey is rather limited to the use of multilevel designs, this number of cases is sufficient if one includes a limited number of country-level variables. ${ }^{3}$ A limited number of countries is especially a problem if one wants to test (interaction) effects on the country level, but as this is not the case in the current analysis, we can be more confident about the validity of our results (Stegmueller, 2013). As a control, in Appendix 2 we also offer a more traditional single-level analysis, using robust standard errors. Furthermore, we will also try to control for the robustness of our findings by conducting a similar analysis on data sets covering more countries.

\section{Measurements}

In this survey, the concept of European identity is measured with two items. One item provides information on feeling European in one's day-to-day life, the other item measures attachment to the European Union. For each respondent the scores on both items are added in a sum scale, which is again rescaled to range from 1 to $4 .^{4}$ A confirmatory factor analysis (CFA) indicates that both items measure the same underlying concept. This CFA is also tested for each country separately and model fit indicators suggest a similar model fit in each country, so we can assume measurement equivalence (results available from the authors).

Trust in the EU institutions was measured with two items measuring trust in the European Parliament and in the European Commission. Both items correlate very strongly (0.83); therefore, scores on both items can be combined in a sum scale in

\footnotetext{
${ }^{3}$ Given the concern about the limited number of country cases, we also opted for an alternative analysis, with pooled data, country dummies, and robust standard errors. This analysis confirms our initial findings (analysis results available from the authors). This makes clear that the results are not due to the limited number of countries participating in this survey.

${ }^{4}$ It has to be noted that we rely here on a sum scale of two items. The questionnaire also included an item about how important an affective attachment to Europe is for being a European. Technically, this third item can be used to construct a measurement scale, with a weak but acceptable Cronbach's $\alpha$ of 0.59 . Using this three-item scale leads to exactly the same results as the one reported in the article. Given the theoretically dubious status of this third item, we prefer the two-item measurement scale.
} 
order to measure trust in the European institutions more generally. For trust in other Europeans, we rely on a single item, measuring 'trust in people from other European countries,' with a 0-10 measurement scale. Although using a single item is not preferable from a methodological point of view, previous studies have indicated that generalized trust is such a strong concept that relying on a single measurement leads to comparable results as relying on a larger battery (Nannestad, 2008). This item also unequivocally taps into the concept that we want to measure, that is, the trust expressed toward inhabitants of other EU member states. While more fine-grained distinctions about trust in specific groups of the European population would have been useful (Gerritsen and Lubbers, 2010), this kind of information is not available in this survey.

On the individual level, controls are included for gender, age, education, origin, political interest, support for EU integration and democratic satisfaction with the EU, as previous research suggests that all these variables are related to European identity. In general, the level of European identity is lower among women than among men (Hooghe et al. 2009; Berg and Hjerm, 2010; Muñoz et al., 2011; Agirdag et al., 2012). Younger age groups are expected to identify more strongly with the EU because they often were socialized in a country that already was a member of the European Union, which is not necessarily the case for older age cohorts. Respondents who have experienced World War II and the start of the European integration project are expected to have a stronger European identity as well (Risse, 2010). As we expect both ends of the age continuum to have a stronger European identity, we model age as curvilinear effect. Education levels have been found to have a very strong effect on European identity, as those who have pursued higher education have the most positive attitude toward the process of European integration (Fligstein, 2008; Hooghe et al., 2009; Berg and Hjerm, 2010). Citizens that were not born in the EU tend to have a weaker European identity (Agirdag et al., 2012). The data allow making a distinction between native respondents (born in the country of test in which they filled out the survey), intra-EU immigrants (born in another EU member state), European immigrants (born in Europe, but not in a EU member state), immigrants born in Northern America, Japan or Oceania, and respondents born in Asia, Africa or Latin America. As previous studies have also shown the role of political interest, this variable is included as a control as well. Political interest is measured by the question 'How much interest do you generally have in politics?' with response options ranging from none at all, to a lot, on a 4-point Likert scale. We also control for attitude on European integration, as a strong relationship between support for European integration and European identity has been suggested in the literature (Hooghe and Marks, 2005; Beaudonnet and Di Mauro, 2012). The question was asked whether respondents perceive the European membership of their country as 'a good thing,' 'neither a good nor a bad thing,' or 'a bad thing.' A related measurement is how satisfied respondents are with the way the European Union functions as a democracy, with answering possibilities ranging from very dissatisfied to very satisfied (Zmerli and 
Newton, 2008; Hobolt, 2012). Furthermore, controls are included for national political trust, general social trust, and satisfaction with democracy in the country, as these variables control for effects that might not be specific to the EU context (Karp et al., 2003). These controls allow us to be more confident that any relations we might find are not just spurious, due, for example, to a general mood of optimism.

On the country level, we control for perceived corruption operationalized as 'control of corruption' from the Worldwide Governance Indicators (WGI), retrieved from the World Bank and for years of EU membership. The perceived corruption indicator measures 'perceptions of the extent to which public power is exercised for private gain, including both petty and grand forms of corruption' (World Bank, 2013). We use the mean score of corruption control for all 16 member states included in the data set. The data of the WGI were collected among citizens, entrepreneurs, and experts in the public, private, and NGO sectors. It is important to control for this variable as it has been shown that corruption levels are highly salient and have a direct effect on attitudes about the EU and trust in EU institutions (Muñoz et al., 2011; Harteveld et al., 2013). It is argued here that citizens of more corrupt member states tend to search for compensation for the bad governance in their country by relying on the functioning of the European institutions (Arnold et al., 2012). Years of EU membership are included as research has shown that membership matters, in a sense that people get socialized into being part of the EU over time, so the longer their country has been a member of the EU, the more times there has been for socialization and the development of a European identity (Kaina, 2006; Risse, 2010).

\section{Analyses}

Before we start the analysis, we provide a few descriptive statistics about the dependent variable (European identity) and the main explanatory variables (political trust in EU institutions and social trust in European citizens). Descriptives and full question wordings for all other used variables are included in Appendix 1. On average, the respondents obtain a score of $2.66 / 4$ on the European identity scale. The lowest mean score is found in the United Kingdom (2.22/4) and the highest mean score is found in Germany $(2.82 / 4)$. The mean score of political trust in EU institutions is $5.83 / 11$. The lowest mean score is found in Hungary (4.38/11), while the highest mean score is found in Estonia (6.50/11). The mean score for social trust in European citizens is 6.45 . For social trust, Denmark has the highest mean score (7.41/11) and Portugal has the lowest mean score (5.86/11). This distribution is in line with what we know from earlier survey results. At first sight, political trust is more strongly correlated with European identity (Pearson's correlation $=0.344$; $P<0.001$ than social trust (correlation of $0.250 ; P<0.001$ ). These correlations 
clearly suggest that it is useful to perform a multivariate analysis to test whether these relationships remain when controls are included.

The multilevel model is built in three steps (Table 1). First, a null model is estimated, in which only the two-level structure of the data is included, and it appears

Table 1. Multilevel regression model with Europen identity as dependent variable

\begin{tabular}{|c|c|c|c|c|}
\hline & \multicolumn{2}{|c|}{ Control model } & \multicolumn{2}{|c|}{ EU trust model } \\
\hline & $\beta$ & SE & $\beta$ & SE \\
\hline Intercept & $-0.298 * *$ & 0.086 & $-0.214 *$ & 0.092 \\
\hline \multicolumn{5}{|l|}{ Individual level variables } \\
\hline Political trust in EU institutions & & & $0.177 * *$ & 0.011 \\
\hline Social trust in European citizens & & & $0.087 * * *$ & 0.009 \\
\hline Gender: female & $0.049 * *$ & 0.016 & $0.037^{*}$ & 0.016 \\
\hline $\mathrm{Age}^{2}$ & 0.082 & 0.048 & 0.082 & 0.048 \\
\hline Age & -0.011 & 0.048 & 0.003 & 0.047 \\
\hline \multicolumn{5}{|l|}{ Education (ref. higher education) } \\
\hline No schooling & -0.048 & 0.113 & -0.014 & 0.111 \\
\hline Primary education & $-0.185 * * *$ & 0.033 & $-0.148 * * *$ & 0.032 \\
\hline Basic secondary education & $-0.132 * * *$ & 0.028 & $-0.110 * * *$ & 0.028 \\
\hline Vocational secondary & $-0.086 * * *$ & 0.023 & $-0.068 * *$ & 0.023 \\
\hline General secondary & $-0.081 * * *$ & 0.023 & $-0.068 * *$ & 0.023 \\
\hline Still student & -0.047 & 0.045 & -0.049 & 0.044 \\
\hline Other & -0.043 & 0.092 & -0.040 & 0.090 \\
\hline \multicolumn{5}{|l|}{ Origin (ref. native) } \\
\hline Intra-EU immigrant & $0.236 * * *$ & 0.051 & $0.209 * * *$ & 0.050 \\
\hline European immigrant (not EU) & 0.084 & 0.068 & 0.085 & 0.066 \\
\hline Born in Northern America, Japan, or Oceania & -0.055 & 0.160 & -0.013 & 0.157 \\
\hline Born in Asia, Africa, or Latin America & 0.028 & 0.062 & 0.024 & 0.061 \\
\hline Political interest & $0.113 * * *$ & 0.009 & $0.106 * *$ & 0.008 \\
\hline \multicolumn{5}{|l|}{ Support European Integration (ref. bad thing) } \\
\hline Good thing & $0.620 * * *$ & 0.024 & $0.518 * *$ & 0.025 \\
\hline Neither good nor bad & $0.169 * * *$ & 0.031 & $0.125 * * *$ & 0.031 \\
\hline Democratic satisfaction EU & $0.154 * * *$ & 0.009 & $0.112 * * *$ & 0.009 \\
\hline Democratic satisfaction country & $0.046 * * *$ & 0.010 & $0.049 * * *$ & 0.010 \\
\hline Political trust in national institutions & $0.087 * * *$ & 0.011 & -0.016 & 0.012 \\
\hline General social trust & 0.012 & 0.009 & $-0.031 * *$ & 0.009 \\
\hline \multicolumn{5}{|l|}{ Country-level variables } \\
\hline Level of Perceived Corruption & -0.015 & 0.052 & 0.021 & 0.056 \\
\hline Years of EU membership & -0.002 & 0.003 & -0.003 & 0.003 \\
\hline Variance level 2 & 0.033 & 0.012 & 0.038 & 0.014 \\
\hline Variance level 1 & 0.736 & 0.009 & 0.713 & 0.009 \\
\hline ICC & \multicolumn{2}{|c|}{$4.3 \%$} & \multicolumn{2}{|c|}{$5.1 \%$} \\
\hline Log likelihood & \multicolumn{2}{|c|}{$-15,395.514$} & \multicolumn{2}{|c|}{$-15,205.831$} \\
\hline
\end{tabular}

Source: IntUne Mass Survey (Cotta et al., 2009) and World Bank (2013).

$N($ level 1$)=12,143 ; N($ level 2$)=16 ; * P<0.05 ; * P<0.01 ; * * P<0.001$.

Variance level 1 in null model: 0.924, variance level 2 in null model: 0.040. 
that $4.1 \%$ of the variation is situated at the country level, which renders the multilevel analysis meaningful.

In the second step, the control variables are added to the model. Standardized regression coefficients $(\beta)$ are given for non-binary variables in order to be able to compare the size of the effects. Against our expectations, female respondents have a slightly stronger European identity than male respondents. The lower the educational level of a respondent, the weaker the European identity, as compared with higher educated respondents. Respondents who were born outside the country of test, but in another EU member state, identify more strongly as European as well. This confirms the expectation that transnational relocations, but within the EU, strengthen European identity. More politically interested respondents also have a significantly stronger European identity. Furthermore, we see that support for European integration is positively correlated to European identity. Both respondents who think EU integration is a good thing and respondents who think membership is neither good nor bad for their country, tend to identify more strongly as EU citizens than respondents who do not support EU integration. Finally, we find that respondents who are more satisfied with democracy in the EU have a stronger European identity and this is indeed a rather strong relationship. We also find a significant relationship for democratic satisfaction in the country, but this relationship is significantly weaker than the relationship between democratic satisfaction in the EU and European identity. For national political trust, we find a positive relationship with European identity as well. Age is not significantly related to strength of European identity and neither is the control, general social trust. At the country level, we find that there is no significant relationship between the perceived level of corruption in a member state and European identity, nor for years of EU membership. ${ }^{5}$ The variance in European identity among individuals is lowered by $20.3 \%$ by including these control variables. The unexplained variance on the country level decreased $17.5 \%$. As neither of the country-level variables is significantly correlated to the strength of European identity, this indicates that the individual differences between respondents are also unequally distributed between member states.

In the third step, the explanatory variables are included in the model. Political trust in EU institutions and trust in European citizens both prove to be significantly and positively correlated with European identity. The effect of political trust, however, is much stronger than the effect of social trust. Although both forms of trust obviously play a role, the results suggest that trust in the EU institutions is more important than trust in fellow European citizens. Including both trust measurements in the model adds $3.1 \%$ to the explained variance at the individual level (level 1), and the rise in log likelihood also shows that this model fits the data

\footnotetext{
${ }^{5}$ In a distinct analysis, we also included an interaction effect between trust in political institutions and length of EU membership. This interaction effect was significant but substantially very weak, and it did not add to the explained variance of the model.
} 
better than the control model. Therefore, including these two measurements clearly adds to the explained variance and we can be confident that these two variables really add to the explanatory power of the analysis. Also, we see that the bivariate relationship between both trust variables and European identity remains significant, so the results in the EU trust model show that the finding that political trust in EU institutions is more strongly correlated to European identity than social trust in European citizens is robust. This result is especially important as we also included political trust in national institutions and general social trust as control variables. The former loses its significance when EU political trust is included, so the relationship between political trust and European identity is clearly driven by trust in EU institutions specifically. General social trust only becomes significant when EU specific trust is included in the model. Moreover, general social trust is, in this model, negatively related to European identity, assumedly because this variable mostly measures national generalized trust as specific European general trust is controlled for. ${ }^{6}$ As the number of cases for multilevel research is rather limited, we also conducted an alternative test, relying on robust standard errors and country dummies. The results of this analysis (Appendix 2) are identical to the results reported in Table 1, leading to more confidence that the results are not due to the specific method of analysis.

As was already mentioned, the IntUne survey remained limited to 16 countries, and this is on the low side if our goal is to conduct valid multilevel research. Therefore, we have included additional robustness checks, trying to replicate our analysis on comparative surveys including a larger number of countries. Unfortunately, very few surveys include all the variables we need for our analysis. In fact, the European Electoral Study of 2004 was one of the few surveys where trust in other European citizens was included, though operationalized in a different manner. If we take on this measurement, however, we do observe (Appendix 3) that results are very similar and that we find a stronger relation between European identity and political trust, than between European identity and trust in other Europeans. Analyses based on the Eurobarometer and the European Election Survey 2014, unfortunately, do not allow us to investigate the effect of trust in other European citizens. They do show, however, that trust in political institutions is very closely related to European identity. While not a single one of these robustness checks includes all the information that we ideally would like to include, they all point to the same conclusion, that is, that there is a close relation between political trust and European identity. As a result, we can be more confident in the robustness of our findings.

\footnotetext{
${ }^{6}$ It has to be noted that the significance of these results is not an artefact of the high number of respondents included in this survey. Using random subsamples of about one third of all respondents confirm that the relation is significant and substantially important. Including the countries one by one from the analysis also confirms that the relation is not due to any outliers.
} 


\section{Discussion}

The results of this analysis first show that European identity is more strongly related to individual level factors than to country-level differences. Despite the fact that countries differ in their policy toward the European Union and their length of membership, most of the factors related to European identity clearly operate on the individual level, although it has to be noted that our data are limited to 16 member states, so it would be interesting to ascertain whether similar conclusions hold if we could include all 28 member states. To some extent our findings confirm earlier results, as highly educated respondents and respondents with high levels of political interest identify more strongly with the European Union. In that regard, our results mainly confirm previous insights. They hint at the fact, however, that citizens with a more privileged situation in society, in general, will have a more positive attitude toward the process of European integration than citizens with a lower socio-economic status.

Turning to our variables of interest in this study, it is obvious that our results provide some support for both approaches to the correlates of European identity. The society-based approach is supported by the finding that trust in other European citizens is significantly associated with European identity. The claim that a European community of citizens is associated with a level of trust among these citizens is therefore in line with the results from our study. As Habermas and other authors have claimed, the project of European integration also requires that citizens of Europe communicate with each other, become acquainted with one another and envision a common European future. Efforts to build a strong European citizenry by stimulating contacts between citizens of different member states thus might seem a promising way to strengthen European citizenship, and this could be associated with stronger beliefs in the legitimacy of the European institutions.

However, the main result of our analysis is that the relation with trust in the political institutions of the EU is much stronger than the relation with social trust in other European citizens. This is clearly compatible with what would be expected from an institutionalist point of view, if the European institutions succeed in building a solid and trustworthy reputation for themselves, the end result might be a further consolidation of the feeling of belonging to the EU community. Although it is important not to disqualify the societal approach to the development of European identity, it should be clear, as well, that institutions are at least equally important in this regard. Society-based approaches toward the development of European identity have often received the criticism that they tend to neglect the role of political institutions in encouraging a feeling of belonging to the EU community. In the work of Habermas too, who can be considered as the most influential author in this field, the community of citizens is often portrayed as a free-floating discourse space, without a clear institutional infrastructure. The current analysis suggests, however, that such an institutional structure is vital. Simply consolidating a community of European citizens, as Habermas envisions, by itself will not be sufficient to help to solidify the 
European Union as a legitimate political actor. More importantly, the European institutions themselves have an important role to play in this regard, and this role is not always taken up sufficiently in the ongoing debate about the development of European identity. If the institutions function in such a manner that citizens place more trust in these European institutions, this should be strongly and positively associated with European identity. Self-evidently there is no direct or immediate relation between the functioning of political institutions and levels of political trust, but in general there is a positive correlation between both measurements as citizens do evaluate the way in which institutions take up their tasks within society.

The finding that trust in the EU institutions is strongly related to a European identity leads to a number of new questions. First of all, it has to be acknowledged that the current cross-sectional analysis does not inform us about the causality involved in this relation, or whether indeed there is any causality. In line with most of the literature, we have assumed in this article that those who have a positive evaluation of the EU institutions are more likely to develop a sense of European identity, but the causal arrow might as well be reversed, or other factors might be responsible for the observed correlation. One could also assume that citizens who identify more strongly with the European Union will develop higher levels of trust in the political institutions of that policy level. As has been mentioned, however, we find very similar results, if we do not include trust in the EU institutions, but trust in the national political institutions as an independent variable. This renders the opposite causal logic more unlikely. It is hard to think of a good reason why citizens who feel European should have higher levels of trust in the national political institutions. A conservative conclusion, however, has to be that the current analysis shows a strong correlation between trust in political institutions and European identity, but that self-evidently longitudinal data would be necessary to investigate causal relations in this regard. It also has to be acknowledged that, despite the fact that we did include a rather wide array of control variables, in this kind of analysis we cannot exclude the possibility of spurious relations to occur, so we cannot make any claims with regard to clear causality.

If there is such a strong relation between trust in the political institutions and European identity, this might still be explained in two different manners. On a more negative note, it could be stated that this indicates that the process of European integration is experienced as an elite-initiated process. Only those citizens who have trust in the political institutions, are likely to identify with the new community that has been established by these political elites. In these analyses, too, the institutions clearly are the driving force for further European integration, not the citizens of the European Union themselves. On the other hand, however, we should also take into consideration what this teaches us about the development of collective identities in general. In the past too, political leaders and institutions have played a crucial part in the process of nation-building. These institutions function as a rally point and as a symbol for the national community. What we have established here is that the European institutions might play a similar role in the process of European 
integration. Whether this warrants the critique that the project of European integration is elite-driven, is a question that can only be answered in an unequivocal manner if the development of European identities is compared with the historical processes that have led to the formation of other collective and political identities. What is clear, however, is that it would be ill advised to place all expectations on society and citizens, in the hope that some form of shared European identity will miraculously emerge from social interaction. The way the European institutions function, and deliver according to expectations, obviously is an element that should receive more attention in the debate on the legitimacy of European integration.

\section{Acknowledgments}

The authors thank the European Research Council for the ERC Advanced Grant 295920 'Democratic Linkage between Citizens and the State in Europe.'

\section{References}

Agirdag, O., P. Huyst and M. Van Houtte (2012), 'Determinants of the formation of a European identity among children: individual- and school-level influences', Journal of Common Market Studies 50: 198-213.

Arnold, C., E.V. Sapir and G. Zapryanova (2012), 'Trust in the institutions of the European Union: a cross-country examination', European Integration Online Papers 16: article 8.

Beaudonnet, L. and D. Di Mauro (2012), 'Support for Europe: assessing the complexity of individual attitudes', European Integration Online Papers 16: article 9.

Beetham, D. and C. Lord (1998), Legitimacy in the European Union, London: Longman.

Berg, L. and M. Hjerm (2010), 'National identity and political trust', Perspectives on European Politics and Society 11: 390-407.

Boomgaarden, H., A. Schuck, M. Elenbaas and C. de Vreese (2011), 'Mapping EU attitudes: conceptual and empirical dimensions of Euroscepticism and EU support', European Union Politics 12: 241-266.

Braun, D. and M. Tausendpfund (2014), 'The impact of the Euro crisis on citizens' support for the European Union', Journal of European Integration 36: 231-245.

Brewer, M.B. (2001), 'The many faces of social identity: implications for political psychology', Political Psychology 22: 115-125.

Bruter, M. (2003), 'Winning hearts and minds for Europe: the impact of news and symbols on civic and cultural European identity', Comparative Political Studies 36: 1148-1179.

— (2008), 'Identity in the European Union - problems of measurement, modelling \& paradoxical patterns of influence', Journal of Contemporary European Research 4: 273-285.

Checkel, J. and P. Katzenstein (eds) (2009), European Identity, Cambridge: Cambridge University Press.

Citrin, J. and J. Sides (2004), 'More than nationals: how identity choice matters in the new Europe', in R.K. Herrmann, T. Risse and M.B. Brewer (eds), Transnational Identities: Becoming European in the EU, Totowa: Rowman \& Littlefield, pp. 161-185.

Cook, K. (ed.) (2001), Trust and Society, New York: Russell Sage Foundation.

Cotta, M., P. Isernia and P. Bellucci (2009), IntUne Mass Survey Wave 2, 2009. Dataset reference 34373, available through ICPSR data archive, Ann Arbor.

Delhey, J. (2007), 'Do enlargements make the European Union less cohesive? An analysis of trust between EU nationalities', Journal of Common Market Studies 45: 253-279.

De Vroome, T., M. Hooghe and S. Marien (2013), 'The origins of generalized and political trust among immigrant minorities and the majority population in the Netherlands', European Sociological Review 29: 1336-1350. 
Duchesne, S. and A.-P. Frognier (2008), 'National and European identifications: a dual relationship', Comparative European Politics 6: 143-168.

Easton, D. (1965), A Framework for Political Analysis, Englewood Cliffs, NJ: Prentice Hall.

- (1975), 'A re-assessment of the concept of political support', British Journal of Political Science 5(4): $435-457$.

EES (2004), European Election Survey dataset, Mannheim: MZES. Retrieved from http://eeshomepage.net.

Faas, D. (2007), 'Youth, Europe and the nation: the political knowledge, interests and identities of the new generation of European youth', Journal of Youth Studies 10: 161-181.

Fligstein, N. (2008), Euroclash: The EU, European Identity and the Future of Europe, Oxford: Oxford University Press.

Fligstein, N., A. Polyakova and W. Sandholtz (2012), 'European integration, nationalism and European identity', Journal of Common Market Studies 50: 106-122.

Føllesdal, A. (2006), 'Survey article: the legitimacy deficits of the European Union', The Journal of Political Philosophy 14: 441-468.

Gerritsen, D. and M. Lubbers (2010), 'Unknown is unloved? Diversity and inter-population trust in Europe', European Union Politics 11(2): 267-287.

Habermas, J. (2011), Sur Verfassung Europas: Ein Essay, Frankfurt: Suhrkamp.

Haller, M. (2008), European Integration as an Elite Process. The Failure of a Dream?, London: Routledge.

Harteveld, E., T. van der Meer and C.E. de Vries (2013), 'In Europe we trust? Exploring three logics of trust in the European Union', European Union Politics 14: 542-565.

Herrmann, R. and M.B. Brewer (2004), 'Identities and institutions: becoming European in the EU', in R.K. Herrmann, T. Risse and M.B. Brewer (eds), Transnational Identities: Becoming European in the EU, Totowa: Rowman \& Littlefield Publishers, pp. 1-22.

Hobolt, S.B. (2012), 'Citizen satisfaction with democracy in the European Union', Journal of Common Market Studies 50: 88-105.

Hooghe, L. and G. Marks (2005), 'Calculation, community and cues: public opinion on European integration', European Union Politics 6: 419-443.

Hooghe, M., T. Reeskens, D. Stolle and A. Trappers (2009), 'Ethnic diversity and generalized trust in Europe: a cross-national multilevel study', Comparative Political Studies 42: 198-223.

Hox, J.J. (2010), Multilevel Analysis: Techniques and Applications, London: Routledge.

Jentges, E., H.-J. Trenz and R. Vetters (2007), 'Von der politischen zu sozialen Konstitutionalisierung Europas. Verfassungsgebung als Katalysator europäischer Vergesellschaftung?', Politische Vierteljahresschrift 48: 705-729.

Kaina, V. (2006), 'European identity, legitimacy, and trust: conceptual considerations and perspectives on empirical research', in I.P. Karolewski and V. Kaina (eds), European Identity: Theoretical Perspectives and Empirical Insights, Berlin: Lit Verlag, pp. 113-146.

- (2009), Wir in Europa. Kollektive Identität und Demokratie in der Europäischen Union, Wiesbaden: VS Verlag für Sozialwissenschaften.

Karp, J., S. Banducci and S. Bowler (2003), 'To know it is to love it? Satisfaction with democracy in the European Union', Comparative Political Studies 36(3): 271-292.

Klingemann, H.-D. and S. Weldon (2013), 'A crisis of integration? The development of transnational dyadic trust in the European Union, 1954-2004', European Journal of Political Research 52: 457-482.

Loveless, M. and R. Rohrschneider (2011), 'Public perceptions of the EU as a system of governance', Living Reviews in European Governance 6: 1-37.

Marien, S. (2011), 'The effect of electoral outcomes on political trust. A multi-level analysis of 23 countries', Electoral Studies 30: 712-726.

Mitchell, K. (2015), 'Rethinking the 'Erasmus Effect' on European identity', Journal of Common Market Studies 53(2): 330-348.

Moravcsik, A. (2002), 'Reassessing legitimacy in the European Union', Journal of Common Market Studies 40: 603-624.

Muñoz, J., M. Torcal and E. Bonet (2011), 'Institutional trust and multilevel government in the European Union: congruence or compensation?', European Union Politics 12: 551-574. 
Nannestad, P. (2008), 'What we have we learned about generalized trust, if anything?', Annual Review of Political Science 11: 413-436.

Norris, P. (2011), Democratic Deficit. Critical Citizens Revisited, Cambridge: Cambridge University Press.

Pierson, P. (1996), 'The path to European integration: a historical institutionalist analysis', Comparative Political Studies 20: 123-163.

Putnam, R. (1993), Making Democracy Work. Civic Traditions in Modern Italy, Princeton: Princeton University Press.

Risse, T. (2010), A Community of Europeans? Transnational Identities and Public Spheres, Ithaca: Cornell University Press.

- (2014), 'No demos? Identities and public spheres in the Euro Crisis', Journal of Common Market Studies 52(6): 1207-1215.

Sanders, D., P. Magalhães and G. Toka (eds) (2012), Citizens and the European Polity. Mass Attitudes Towards the European and National Polities, Oxford: Oxford University Press.

Scheuer, A. and H. Schmitt (2009), 'Dynamics in European political identity', Journal of European Integration 31: 551-568.

Shore, C. (2000), Building Europe: The Cultural Politics of European Integration, London: Routledge.

Sigalas, E. (2010), 'Cross-border mobility and European identity: the effectiveness of intergroup contact during the ERASMUS year abroad', European Union Politics 11: 241-265.

Stegmueller, D. (2013), 'How many countries for multilevel modeling? A comparison of frequentist and bayesian approaches', American Journal of Political Science 57: 748-761.

Tilly, C. (ed.) (1975), The Formation of National States in Western Europe, Princeton: Princeton University Press.

- (1992), Coercion, Capital, and European states, AD 990-1992, Cambridge, MA: Blackwell.

Uslaner, E.M. (2002), The Moral Foundations of Trust, Cambridge: Cambridge University Press.

Verhaegen, S., M. Hooghe and E. Quintelier (2014), 'European identity and support for European integration: a matter of perceived economic benefits?', Kyklos 67: 295-314.

World Bank (2013), 'Worldwide Governance Indicators'. Retrieved from http://info.worldbank.org/governance/wgi/resources.htm\#sources.

Zmerli, S. and K. Newton (2008), 'Social trust and attitudes toward democracy', Public Opinion Quarterly 72: 706-724.

Zmerli, S. and M. Hooghe (eds) (2011), Political Trust: Why Context Matters, Colchester: ECPR Press. 


\section{Appendix}

Appendix 1. Question wording and descriptives

\begin{tabular}{|c|c|c|c|c|}
\hline Variable & Question wording & Mean & Minimum & Maximum \\
\hline \multirow[t]{2}{*}{$\begin{array}{c}\text { European } \\
\text { identity }\end{array}$} & $\begin{array}{l}\text { How much does being a European have to do with } \\
\text { how you feel about yourself in your day to day life? }\end{array}$ & 2.483 & 1 & 4 \\
\hline & $\begin{array}{l}\text { People feel different degrees of attachment to their } \\
\text { town or village, to their region, to their country and } \\
\text { to Europe. What about you? Are you very attached, } \\
\text { somewhat attached, not very attached or not at all } \\
\text { attached to <Europe }>\text { ? }\end{array}$ & 2.829 & 1 & 4 \\
\hline Age & $\begin{array}{l}\text { Could you please tell me the year in which you were } \\
\text { born? }\end{array}$ & 47.55 & 16 & 101 \\
\hline Political interest & How much interest do you generally have in politics? & 2.686 & 1 & 4 \\
\hline $\begin{array}{l}\text { Democratic } \\
\text { satisfaction EU }\end{array}$ & $\begin{array}{l}\text { On the whole, how satisfied are you with the way } \\
\text { democracy works in the European Union? }\end{array}$ & 2.610 & 1 & 4 \\
\hline \multirow[t]{3}{*}{$\begin{array}{l}\text { Political trust EU } \\
\text { institutions }\end{array}$} & $\begin{array}{l}\text { Please tell me on a scale of } 0-10 \text {, how much you } \\
\text { personally trust each of the following institutions to } \\
\text { usually take the right decisions }\end{array}$ & & & \\
\hline & - The European Parliament & 5.809 & 1 & 11 \\
\hline & - The European Commission & 5.852 & 1 & 11 \\
\hline \multirow[t]{2}{*}{$\begin{array}{l}\text { Social trust in } \\
\text { European } \\
\text { citizens }\end{array}$} & $\begin{array}{l}\text { Please tell me on a scale of } 0-10 \text {, how much you } \\
\text { personally trust each of the following groups of } \\
\text { people }\end{array}$ & & & \\
\hline & - People in other European countries & 6.449 & 1 & 11 \\
\hline $\begin{array}{l}\text { General social } \\
\text { trust }\end{array}$ & $\begin{array}{l}\text { Generally speaking, would you say that most people } \\
\text { can be trusted or that you need to be very careful in } \\
\text { dealing with people? Please use a number between } 0 \\
\text { and } 10 \text {, where ' } 0 \text { ' means that 'you need to be very } \\
\text { careful in dealing with people', and ' } 10 \text { ' means that } \\
\text { 'most people can be trusted'. You can use any } \\
\text { number from } 0-10\end{array}$ & 6.449 & 1 & 11 \\
\hline \multirow[t]{4}{*}{$\begin{array}{l}\text { Political trust } \\
\text { national } \\
\text { institutions }\end{array}$} & $\begin{array}{l}\text { Please tell me on a scale of } 0-10 \text {, how much you } \\
\text { personally trust each of the following institutions to } \\
\text { usually take the right decisions }\end{array}$ & & 1 & 11 \\
\hline & - The national parliament & 5.455 & & \\
\hline & - The national government & 5.349 & & \\
\hline & - The regional or local government & 6.077 & & \\
\hline \multirow{2}{*}{$\begin{array}{l}\text { Democratic } \\
\text { satisfaction } \\
\text { country }\end{array}$} & $\begin{array}{l}\text { On the whole, how satisfied are you with the way } \\
\text { democracy works in [country of test]? }\end{array}$ & 2.361 & 1 & 4 \\
\hline & $\begin{array}{l}\text { Combined measurement of perceptions of the extent to } \\
\text { which public power is exercised for private gain, } \\
\text { including both petty and grand forms of corruption } \\
\text { as measured among citizens, entrepreneurs and } \\
\text { experts in the public, private and NGO sectors by } \\
\text { World Bank }\end{array}$ & 1.003 & -0.195 & 2.441 \\
\hline $\begin{array}{l}\text { Years of EU } \\
\text { membership }\end{array}$ & Based on year of accession to the EU & 26.43 & 2 & 52 \\
\hline \multirow[t]{2}{*}{ Gender } & Male & $48.75 \%$ & & \\
\hline & Female & $51.25 \%$ & & \\
\hline
\end{tabular}


Appendix 1. (Continued)

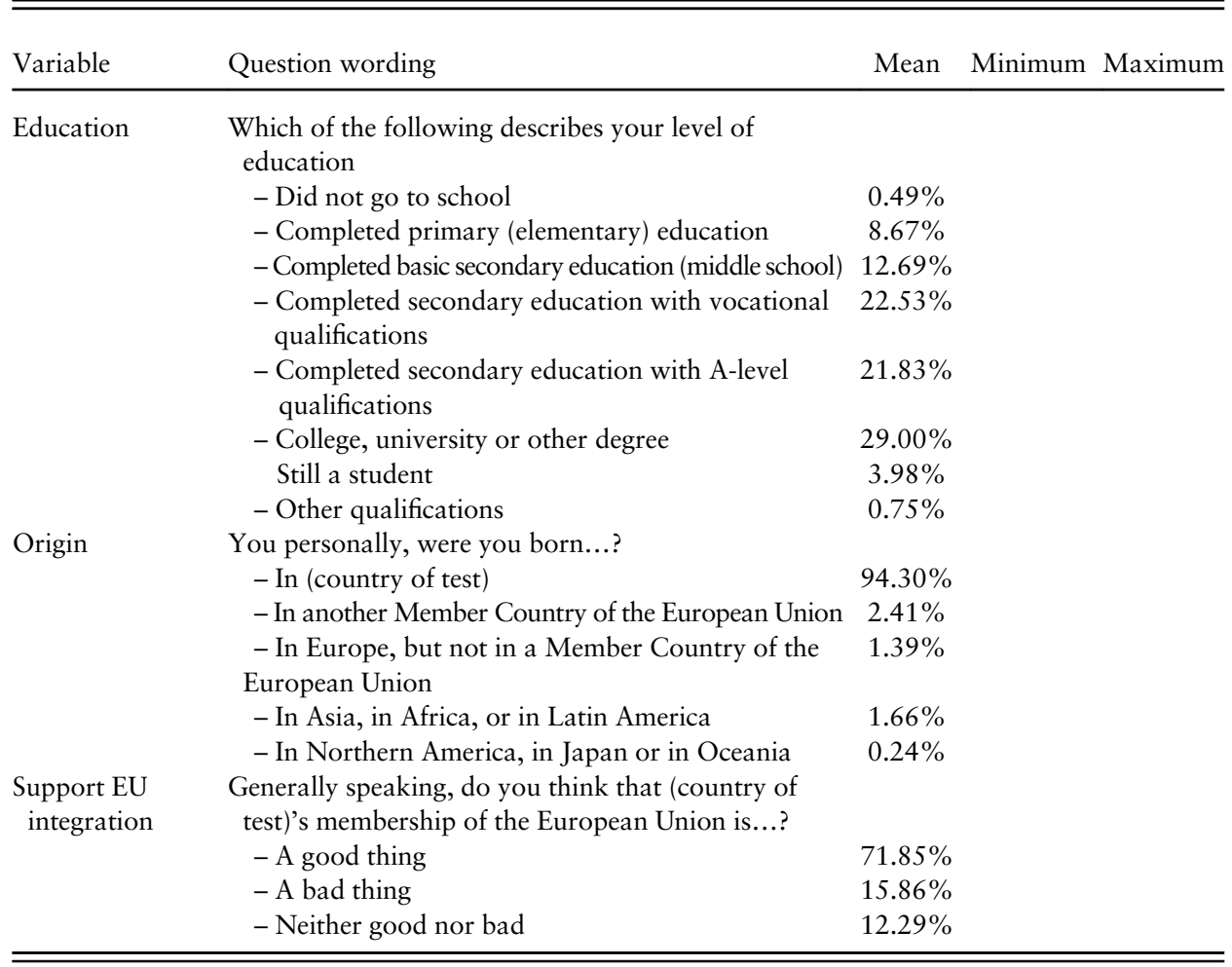

Source: IntUne Mass Survey (Cotta et al., 2009) and World Bank (2013). 
Appendix 2. Analysis with clustered standard errors and country dummies

\begin{tabular}{|c|c|c|}
\hline & \multicolumn{2}{|c|}{ Control model } \\
\hline & $\beta$ & SE \\
\hline Intercept & $-0.298 * * *$ & 0.034 \\
\hline \multicolumn{3}{|l|}{ Individual-level variables } \\
\hline Political trust in EU institutions & $0.178 * * *$ & 0.027 \\
\hline Social trust in European citizens & $0.087 * * *$ & 0.009 \\
\hline Gender: female & 0.037 & 0.022 \\
\hline Age & -0.003 & 0.048 \\
\hline $\mathrm{Age}^{2}$ & 0.082 & 0.047 \\
\hline \multicolumn{3}{|l|}{ Education (ref. higher education) } \\
\hline No schooling & -0.014 & 0.104 \\
\hline Primary education & $-0.149 * *$ & 0.037 \\
\hline Basic secondary education & $-0.112 * *$ & 0.023 \\
\hline Vocational secondary & $-0.070 *$ & 0.029 \\
\hline General secondary & $-0.070 *$ & 0.028 \\
\hline Still student & -0.050 & 0.042 \\
\hline Other & -0.041 & 0.111 \\
\hline \multicolumn{3}{|l|}{ Origin (ref. native) } \\
\hline Intra-EU immigrant & $0.208 *$ & 0.098 \\
\hline European immigrant (not EU) & 0.087 & 0.104 \\
\hline Born in Northern America, Japan or Oceania & -0.011 & 0.154 \\
\hline Born in Asia, Africa or Latin America & 0.024 & 0.070 \\
\hline Political interest & $0.106 * * *$ & 0.010 \\
\hline \multicolumn{3}{|l|}{ Support European Integration (ref. bad thing) } \\
\hline Good thing & $0.518 * * *$ & 0.037 \\
\hline Neither good nor bad & $0.124 *$ & 0.043 \\
\hline Democratic satisfaction EU & $0.112 * * *$ & 0.009 \\
\hline Democratic satisfaction country & $0.049 * *$ & 0.014 \\
\hline Political trust in national institutions & -0.017 & 0.022 \\
\hline General social trust & $-0.031 * *$ & 0.010 \\
\hline \multicolumn{3}{|l|}{ Country dummies (Belgium is ref.) } \\
\hline Denmark & 0.013 & 0.020 \\
\hline Germany & $0.178 * * *$ & 0.013 \\
\hline Greece & $-0.301 * * *$ & 0.018 \\
\hline Spain & $-0.112 * * *$ & 0.007 \\
\hline France & $-0.103 * * *$ & 0.012 \\
\hline Italy & $0.050 * *$ & 0.014 \\
\hline Portugal & $0.241 * * *$ & 0.013 \\
\hline United Kingdom & $-0.351 * * *$ & 0.020 \\
\hline Estonia & $-0.082 * * *$ & 0.014 \\
\hline Hungary & $0.496 * *$ & 0.028 \\
\hline Poland & $0.184 * * *$ & 0.015 \\
\hline Slovakia & -0.004 & 0.014 \\
\hline Slovenia & $-0.053 * *$ & 0.013 \\
\hline Bulgaria & $-0.073 *$ & 0.028 \\
\hline Austria & $0.219 * * *$ & 0.021 \\
\hline$R^{2}$ & \multicolumn{2}{|c|}{$26.14 \%$} \\
\hline
\end{tabular}

Source: IntUne Mass Survey (Cotta et al., 2009)..

$N($ level 1$)=12,143 ;{ }^{*} P<0.05 ; * P<0.01 ; * * * P<0.001$. 
Appendix 3. Results of a replication based on EES (European Election Survey) 2004

\begin{tabular}{lcc}
\hline \hline & $\beta$ & SE \\
\hline Intercept & $-0.469^{* * * *}$ & 0.063 \\
Gender: female & -0.039 & 0.021 \\
Age $^{2}$ & 0.003 & 0.118 \\
Education (age stopped full-time education) & $0.041^{* * *}$ & 0.012 \\
Political interest & $0.120^{* * * *}$ & 0.012 \\
Support European Integration (ref. bad thing) & & \\
$\quad$ Good thing & $0.839^{* * * *}$ & 0.038 \\
$\quad$ Neither good nor bad & $0.327^{* * * *}$ & 0.038 \\
Democratic satisfaction EU & $0.127^{* * *}$ & 0.013 \\
Political trust in EU institutions & $0.167^{* * * *}$ & 0.013 \\
Social trust in European citizens & $0.109^{* * * *}$ & 0.012 \\
& & \\
Variance level 2 & 0.047 & 0.017 \\
Variance level 1 & 0.585 & \\
ICC & $7.4 \%$ & 0.011 \\
Log likelihood & -6218.335 & \\
$N$ (level 1) & 5382 & \\
$N$ (level 2) & 17 & \\
\hline \hline
\end{tabular}

Source: EES (2004).

$* P<0.05 ; * P<0.01 ; * * P<0.001$. 